This is the accepted manuscript (post-print version) of the article. As regards to content, the postprint version is identical to the final published version, but there may be differences in typography, layout, and copy editing.

Please cite the published version: Liebst, Lasse Suonperä and Sam Griffiths. 2019. Space syntax theory and Durkheim's social morphology: a reassessment. Distinktion: Journal of Social Theory https://doi.org/10.1080/1600910X.2019.1641121

\title{
Space syntax theory and Durkheim's social morphology: a reassessment
}

\author{
Lasse Suonperä Liebst and Sam Griffiths
}

\begin{abstract}
In outlining their influential architectural theory of space syntax, Hillier and Hanson acknowledge its affinity to Durkheim's classical sociology, including his social morphological considerations on the spatial basis of social life. In doing so, space syntax theory promised to address the then woefully under-theorised relationship between society and space, specifically by emphasising the agency of spatial-morphological arrangements. Given the Durkheimian inspiration, it is surprising that sociology has been so silent on the subject of space syntax theory. This lack of dialogue may be explained by the gestation of space syntax research within the specialist disciplinary silo of architectural theory, as well as by the default sociological assessment that formal methodologies of spatial analysis, such as those associated with space syntax, sustain a discredited fallacy of physical determinism. Yet, intellectually this situation is unfortunate: while sociology overlooks how space syntax theory has advanced the Durkheimian understanding of spatial morphologies, space syntax theory misses an opportunity to update and broaden its notion of social processes. In response, this article revisits Durkheim's social morphology and reviews the analytical strengths and deficits of Hillier and Hanson's consideration of Durkheimian theory. We identify how difficulties arise because of an over-reliance of space syntax theory on the structural functionalist macro-wing of the Durkheimain tradition. To address this issue, we prepare the ground for a theoretical engagement between space syntax and the micro-sociological branch of the Durkheiminan scholarship, and show how this tradition offers a more coherent means for translating the spatio-morphological insights of space syntax theory into contemporary debates in the sociology of space.
\end{abstract}




\section{Introduction}

Space is on the sociological research agenda. It is currently argued that social theory is turning towards a wider appreciation of space (Warf and Arias 2008), implying that spatiality should be regarded a novel aspect of sociological inquiry (Latour 1996, Latour and Yaneva 2008). As highlighted by Tonboe (1993), however, it is misleading to regard space as a "new" sociological dimension. It would be more accurate to say that the spatial dimension has been "lost and found" repeatedly across the sociological tradition, as reflected in the circumstance that the sociological classics previously conceptualised societal processes in the context of space. The tendency to neglect these early contributions is symptomatic for the field of the sociology of space, and this is arguably most conspicuous with regard to one of the founding fathers of French sociology, Émile Durkheim, whose notion of social morphology asserted a role for space in the very heart of sociological inquiry (Tonboe 1993; Liebst 2016; Lindemann 2011). This neglect translates further, as suggested by Smith (1999), into an under-utilisation of the space theoretical contributions found within the Durkheimian tradition, including the work of Mary Douglas (1970), Levi-Strauss (1974), and Victor Turner (1977).

With remarkably few exceptions, it is thus outside mainstream sociology that we find a contemporary contribution that fully acknowledges and Durkheim's theorising on space. The analytical architecture theory of space syntax - paradigmatically set out in Hillier and Hanson's (1984) The Social Logic of Space - incorporates key elements of Durkheim's sociology into its theoretical foundations. Durkheim is also referenced time and again, both in the formative publications leading up to this book (e.g. Hanson 1976; Hillier et al. 1976; 1978) and in the numerous theoretical contributions that followed (e.g. Hillier et al. 1987; Hillier 1989; Hiller and Netto 2002; Hillier 2008; Hillier 2010; Hanson 2012). The space syntax-Durkheim link also manifests itself in the circustance that when other sociological scholars are referenced by Hillier and Hanson, the overwhelming majority are placed within a Durkheimian space-theoretical paradigm. Given this record of engagement, there is a strong - if perhaps somewhat unexpected - case to be made that the space syntax tradition provides one of the most significant elaborations of Durkheim's social morphological theory on offer to contemporary sociologists.

Most sociologists will be unfamiliar with the field of space syntax that emerged in the Bartlett School of Architecture at University College London (UCL) during the 1970s, and which continues to host the Space Syntax Laboratory. The research field now forms a global community, with nodes 
established in schools of architecture and built environment worldwide. ${ }^{1}$ While space syntax provides a useful nexus for interdisciplinary research in built environment its disciplinary positioning is firmly in architecture, where a large number of practising architects - including leading figures such as Norman Foster (1997) - employ space syntax methods as a tool in the design process. Many of these practical applications are, as we shall see below, looking to model the effect of architectural and urban space on human movement.

Space syntax initially arose in response to what its pioneers, most notably Bill Hillier, regarded as the inadequate theorisation of the human-made environment - a situation they believed presented a serious impediment to articulating architectural design knowledge as an autonomous knowledge domain. The need for such an articulation was part of a general response to the perceived crisis of architectural modernism in the late 1960s, as many of the more utopian aspirations for architecture in the post-war era (for example in the design of housing estates and new towns) became increasingly identified with social dysfunction. For Hillier, as for many other architectural thinkers of this era, this crisis suggested a need to rethink the nature of the relationship between architecture and society. In a series of papers in the early 1970s, Hillier and colleagues drew heavily on systems theory and mathematical logic from the emerging field of computer science to question prevailing mechanistic and idealist theories of the human environment in architectural design (Hillier and Leaman 1973a; 1974). Conventionally, this was conceived in terms of direct physicalist determinants, or in socio-psychological terms as a cognitive image of a social totality (Hillier and Leaman 1973b). These simplifications, Hillier argued, elided the distinguishing quality of architectural design that also defined its disciplinary autonomy, namely addressing the relation of form and function in the spatial-morphological environment where social life actually takes place.

While the engagement of space syntax with sociological and Durkheimian scholarship is extensive, sociology on the other hand, offers only few scattered remarks on space syntax (e.g. Löw 2008). These are often rather parenthetical and delivered in a rather dismissive tone, typically expressing distrust for its deployment of formal, analytical methods and certainly without acknowledging the Durkhiemian contribution (e.g. Saunders 2003; Soja 2001). This scepticism may be traced back to an assertion that the space syntax approach commits the same "fallacy of physical determinism", which Gans (1968) famously identified in Jacobs' (1961) architectural thought. Thus, while sociological theories of space tend to "approach the society-environment relation 'society

\footnotetext{
${ }^{1}$ The Proceedings of the International Space Syntax Symposia, held bianually since 1997, are available on open access and offer a good overview of the community's diverse research interests and activities, see spacesyntax.net.
} 
first', in that the form of the environment is sought as the product of the spatial dimensions of social processes", the idea of space syntax theory is, as Hillier $(2008$, p. 1) puts it, "to turn the question the other way round and through 'environment first' studies look for evidence of social processes in the spatial forms of the built environment". For most sociologists, this architectural ambition to study the "real space" of built morphologies reflects an "absolutist" understanding of spatiality, which Löw's (2016) recent contribution has criticised for naively assuming that space exists independently of social action. Sociologists are overall, as summarised by Logan (2012, p. 507), "less interested in spatial patterns in themselves, and more interested in how they translate into social relations."

Yet, as humans are discretely situated individuals in the material world (Turner 2010), there is a need to theorise how our spatio-morphological arrangements enables the construction of social relations across space; a question with clear Durkheimian resonances. In this spirit, the current article proceeds to take some initial steps to establish space syntax as an important Durkheimian morphological contribution, highlighting the productive role of society's material organization in generating, constraining, and assembling social relations. In our view, the current state of affairs is counterproductive for the theoretical advancement of space syntax and sociology: while space syntax theory misses a challenging interdisciplinary opportunity to update and broaden its understanding of social processes, sociology continues to overlook the original contribution of space syntax to a neo-Durkheimian theory of spatial morphology.

Our attempt to reassess the Durkheimian roots of space syntax will proceed as follows. Initially, the article revisits Durkheim's social-morphological argument that social life rests upon and is shaped by a material substratum. Next, we examine how Hillier and Hanson elaborate the original Durkheimian framework by resolving Durkheim's somewhat ambivalent account of whether morphological space holds real agency. We then consider a number of limitations of Hillier and Hanson's adaptation of Durkheim's social morphology, specifically by developing a critique of the affinity of space syntax to the structural functionalist macro-wing of Durkheimian scholarship. Finally, we suggest that these limitations may be to large extent overcome by recourse to the alternative micro-wing of Durkheimian thought, in particular, Randall Collins' (2004) microsociology that offers a better theoretical match for the methodological contribution of space syntax, which pertain to the fine-grained human-scale of architectural space. 


\section{Revisiting Durkheim's Social Morphology}

An often-neglected aspect of Durkheim's (1978) thinking is how he understood his "general sociology" as having two pillars, that of "social morphology" and "social physiology". Social morphology is the sociological inquiry into the "material substratum" of society, detailed in two components: first, social population, understood as the volume, distribution, and social density of the societal population; and second, the geographical base of social life, that is, the spatial surface on which the population is distributed. The latter spatial dimension includes properties of natural geography and the organisation of the built environment, such as how "the disposition of streets and squares, the architecture of the houses, and the structure of things made vary from village to town and from the large city to the small one, and so on" (Durkheim 1960, p. 361).

Durkheim describes the social morphology as an inquiry into the "anatomy" of society, analogous to the biological study of the morphological "form" of living creatures - the structure and composition of "tissues" and "organs". Keeping to this biological analogy, Durkheim defines the other pillar of his general sociology, "social physiology", as the study of the societal "functions", inherent to this tissue and these societal organs: "Besides the social ways of being, there are the social modes of doing; besides the morphological phenomena, there are the functional or physiological phenomena" (Durkheim 1960, p. 363). This social physiological study of functional “doings" concerns, for example, the sociology of moral and religious institutions. Further, careful to strike a balance between the "real" and "ideal" ontologies of society, Durkheim emphasises that although the functional doings of a society are contingent upon its form-specific manner of material being, the physiological aspects of social life are more varied and complex than its morphological counterpart (Durkheim 1960). The material composition of "people and things", which by necessity are "connected in space", conditions the emergence of a societal complexity whose "whole very often has very different properties from those which its constituent parts possess" (Durkheim 1978, p. 76). Thus, although morphologically anchored, society has a (religious, moral, etc.) existence sui generis, whose social physiological manifestation acts autonomously as a "collective consciousness" of society:

While the different forms of collective activity also have their own substratum and while they derive from it in the last instance, once they exist, they become, in turn, creative sources of action, they have an effectiveness all their own, and they react on the very causes on which they depend (Durkheim 2005b, p. 17). 
Durkheim (1984 [1893]) most fully elaborated the empirical implications of this morphology-physiology nexus in his early masterpiece, The Division of Labour in Society - which is also the Durkheimian text to which space syntax theory gives most weight (see e.g. Hanson 1999; Hillier and Hanson 1984; Hillier and Netto 2002). The moral theoretical (and as such, sociophysiological) question that Durkheim set out to explore in Division is as relevant today as ever: "Why does the individual while becoming more autonomous, depend more upon society? How can he be at once more individual and more solidarity?" (Durkheim 1984, p. 37). Famously, Durkheim suggested that pre-modern and modern societies have distinct types of social solidarity, derived from the level of division of labour within the societies. A "mechanic solidarity" is operative in weakly differentiated pre-modern societies, because of the infinite points of resemblance immediately connecting the individual to the society. As such, solidarity is here experienced as a feeling of oneness among the members of society. By comparison, an "organic solidarity" in modern societies is a product of the growth of the reciprocal interdependences among differentiated individuals, especially in the form of contractual relations on the urban labour market.

What is less appreciated - or even brushed aside as a temporary lapse of scholarly judgement (Alexander 2005) - is that Durkheim offers a social morphological explanation of the social evolutionary process from mechanic to organic solidarity. The division of labour, and the related types of social solidarity, developed as the undifferentiated population segments of premodernity gradually expanded their social relations through space: "The increase in the division of labour is ... due to the fact that the social segments lose their individuality, that the partitions dividing them become more permeable" (Durkheim 1984, p. 200). In other words, it was as the spatial partitions or boundaries of social life became less marked that the social segmentation of pre-modernity was succeeded by the dense population structure, so characteristic of urbanised modernity. Further, this spatial process was promoted by expanding communication and transportation connections across former spatial boundaries, such as infrastructures within and between metropolitan cities. The consequence of this increasing spatial integration was a growing population density, and Durkheim described this "dynamic density" condition as the fundamental generator of social change (see also Durkheim 1966). As such, a high level of social density intensified, in a Darwin-Spencerian sense, "the struggle for existence" and this conflictual situation was, in turn, resolved by the emergence of organic solidarity, generated by the same density condition: "a break in the equilibrium of the social mass gives rise to conflict that can only be 
resolved by a more developed form of the division of labour: this is the driving force for progress" (Durkheim 1984, p. 212).

Space and social morphological factors are assigned a more prominent role in Durkheim's theorising that it is normally acknowledged, but Durkheim also seems to have had an ambivalent, or "shifting attitude" (Schlanger 2006), about standing by the spatio-material explanation that he advances in Division and elsewhere. This may be linked to the circumstance that he was balancing on the ontological edge of his morphology-physiology distinction, assigning a monopoly of societal agency to the physiological face of society. As we recall, the social physiology relates to the functional ways of "doing", whereas social morphology relates to the material modes of "being". This distinction is, furthermore, reflected in his explicit "sociocentrism" (Durkheim and Mauss 1963 ) and related anthropocentric view that rejects ascribing human-like agency to material "nonhuman" actors (Latour 2005). Thus, as regards "things", which would include the spatial artefacts of the social morphology, Durkheim argues in The Rules of Sociological Method that "they contain nothing of what is required to put things in motion. They are matter upon which social forces of society acts, but by themselves they release no social energy" (Durkheim 1966 [1895], p. 113). However ambivalently, in On Suicide Durkheim's highlights that once the "material objects" of society are "built", these materialisations of an architectural, infrastructural, or technological kind become an autonomous reality, independent of individuals and social physiological doings: "Social life, having as it were crystallised itself in this way and fixed itself on material props, is by that very fact exteriorized and acts upon us from outside" (Durkheim 2005a [1897], p. 348).

Durkheim's ambivalence regarding the potential causal forces of morphological properties have posed a puzzle and a point of dispute for generations of Durkheimian scholars and critics (see Alexander 2005; Collins 2005; Douglas 1972; Latour 2005; Liebst 2016). Related to this question, it is also contested whether such materialist considerations should be isolated to Durkheim's early sociology and Division (1984 [1893]), or whether they also extended into his late sociology of religion, as outlined in Elementary Forms of the Religious Life (1995 [1912]). Further, the literature contains few attempts to resolve Durkheim's somewhat ambivalent conceptualisation of his social morphology, by developing plausible accounts of why space should be attributed any agential forces. The profound relevance of Hillier and Hanson's space syntax theory to Durkheimian scholarship is that they offer the most systematic and promising attempt to address this unresolved ambivalence. 


\section{Space Syntax and the Real Agency of Morphological Space}

As the title of Hillier and Hanson's (1984) The Social Logic of Space suggests, the space syntax paradigm should be of at least as much interest to sociology as to architectural research. Their principal focus is on the "society-space relation", reflected in the purpose of establishing a systematic theory on "how spatial pattern can, and does, in itself carry social information and content" (Hillier and Hanson 1984, p. xi). This ambition addresses a paradigmatic deficit of contemporary theories of the society-space relation: "The [predominant] paradigm in effect conceptualises space as being without social content and society without spatial content. Yet neither can be the case, if there is a lawful relation between them" (Hillier and Hanson 1984, p. x). As if to make their point, the geographer Massey $(2005, \mathrm{p} .101)$ argues "[w]hat is always at issue is the content not the spatial form" of social relations. Facing this impasse, Durkheim's social morphology offers, according to Hillier and Hanson, a theoretical exception so extraordinary that they adopt it as a cornerstone of the space syntax paradigm:

Durkheim actually located the cause of the different solidarities in the spatial variables, namely the size and density of populations. In the work of Durkheim, we found the missing component of a theory of space, in the form of the elements for a spatial analysis of social formations. But to develop these initial ideas into a social theory of space, we had to go back once again into the foundations, and consider the sociology of the simplest spatial structure we had found useful to consider: the elementary cell (Hillier and Hanson 1984, p. 18, italics added).

At first, Hillier and Hanson seem loyal to Durkheim's original morphological scheme - yet, the "but" in the passage cited signifies that Hillier and Hanson's contribution is not simply a reiteration of Durkheim's position. Their statement of intent to go back once again into the foundations can be read as an attempt to explicate how the social physiological solidarities of society are contingent upon and, thus, explainable by the "real agency" (Hillier 2005) of the spatial morphology. To understand how they reach this conclusion, let us take as our point of departure where Hillier and Hanson also began, namely the simplest spatial structure in Durkheim's material substratum: the elementary cell.

In developing their "sociology of the elementary cell", Hillier and Hanson (1984, p. xx) define the cell as a spatial difference that makes a social difference through the establishment of a 
sociological distinction between an "inside" and "outside" - we may think of the elementary cell as a simple ground-floor dwelling with a single room and doorway that connects it to the exterior. While interior spaces tend to have well-defined social roles and norms, exterior spaces are often characterised by fewer and less explicit categorical differences; insiders are recognised as the inhabitants, spatially demarcated from the outside world of (urban) strangers by some kind of boundary (Hillier 1989). As such, social relationships may have a "trans-spatial" or "spatial" nature, reflecting whether social group identities persist across space (e.g. family members who maintain their social roles in each other's physical absence), or are merely based on spatial proximity (e.g. encounters between urban strangers). Where a strong "correspondence" exists between social group identity and spatial proximity (for example as in some socially segregated housing estates), the boundary of the local cell is emphasized at the cost of fragmentation of the global (urban) system. Where there is "non-correspondence" between social group identity and defined spatial boundaries (such that one cell is largely interchangeable with another), then the city will be characterised by much local-to-global movement and social mixing.

Hillier and Hanson (1984, p. 19) suggest two pathways of growth from the elementary cell: "it can be by subdividing a cell, or accumulating cells, so that internal permeability is maintained" (i.e., comparable to internal accessibility between different rooms in a building); "or by aggregating them independently, so that the continuous permeability is maintained externally" (i.e. comparable to external accessibility to buildings via an urban street network). These aggregation types are the elementary manifestations of "buildings" and "settlements", respectively, each of which are regulated by distinct sociological roles and norms for how to behave when being inside or outside. Note how this argument resonates with Goffman's (1956) distinction between "front" and "back" spatial regions, describing how social actors conduct themselves differently when inside in private enclosures or outside in front of an audience. The theoretical resemblance is no coincidence, given that Goffman is one of the other few Durkheimian scholars who embraces social morphological insights (Collins 1994; Turner 2010).

Of particular relevance for the resolution of Durkheim's ambivalence, Hillier and Hanson's considerations on the elementary cell imply an assignment of agency to morphological space. The spatial difference between inside and outside makes a social difference because of how the structure of the elementary cells generates and regulates patterns of human movement and social co-presence. As it is highlighted, the spatial morphology 
has a direct relation - rather than a merely symbolic one - to social life, since it provides the material preconditions for the pattern of movement, encounters and avoidance which are the material realisation - as well as sometimes the generator - of social relations (Hillier and Hanson 1984, p. ix).

This argument transcends Durkheim's ambivalence: spatial morphologies affect society because of the network agential impact of real space on dynamic densities. When space syntax theory (and we, in our theorisations) use the term spatial/network agency, it simply refers to independent influence that spatial networks have on movement density patterns (Hillier 2005). What is more, for space syntax theory, this is a testable claim that may be assessed with spacemorphological methods. By comparison, Durkheim offered few methodological guidelines for how morphological space should be empirically examined. Thus, while Durkheim could only speculate on how movement and dynamic densities are shaped by spatial "passage-lines", it is the singular achievement of space syntax methodology to operationalise these passage-lines with topological network representations (or, to use the technical term, "axial-lines graphs"; Hillier and Hanson 1984; Penn 2003). ${ }^{2}$ This approach to capturing the networked nature of real space marked a significant development on the establishment of a primarily descriptive typology of "generative" and "conservative" spatial-morphological systems that had characterised the previous phase of research (Hillier and Hanson 1984; Hillier et al. 1976). Specifically, this new development enabled precise syntactic description at the scale of individual streets, for example quantifying how central or segregated a given street was, relative to others in the same urban system; thereby yielding numeric descriptions that then may be mapped onto other forms of social data (Hillier and Raford 2010).

Using this methodology, a key finding is that spaces centrally located in the wider street network display higher levels of movement flows than disintegrated spaces - a phenomenon known as "natural movement" (Hillier et al. 1993; for meta-analytical evidence on this space-movement association, see Sharmin and Kamruzzaman 2018). Thus, contrary to predominantly non-morphological view of most urban and space sociology (Gans 2002; Löw 2016), which would explain such variations in human movement as an product of social action and emplaced attractors, space syntax proposes that it is the street grid configuration that generates these movement inequalities and land

\footnotetext{
2 An axial line graph is the least number and longest length of straight lines that cover a contiguous area of open space in any settlement or building. See Hillier and Hanson (1984) for details of the method.
} 
use attractions (e.g. hot spots of shops or lively streets) in the first place. Further, due to its material articulation, configurational space is not reciprocally shaped by the patterns of movement and land use attraction, although such relations may be proposed over historical timescales (Griffiths 2011). The practical implication of this robust space-movement association is that architects and urban planners have successfully applied space syntax methods to evaluate the movement behavioural consequences of architectural layouts (for examples of real-world applications, see Karimi 2012).

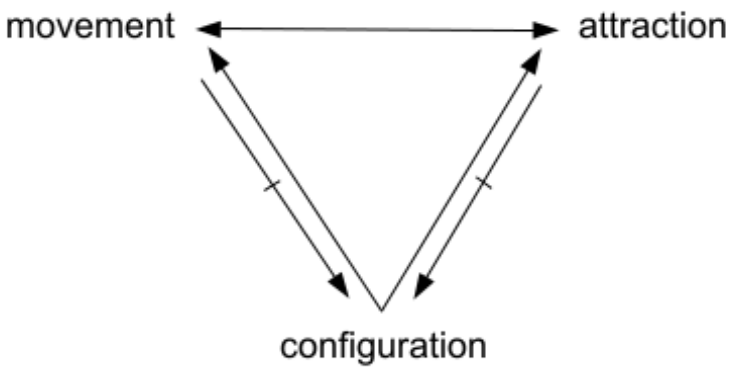

Figure 1. Configuration as generative of movement and attraction (Hillier et al. 1993).

Here, we should note that space syntax is not the first Durkheimian attempt to make a methodological contribution to the space-morphological study of the material substratum. This is evidenced by the endeavours of Durkheim's contemporary students, including Mauss (1979 [1906]) and Halbwachs (1960). As Mauss (2005) acknowledged, however, these innovative early contributions were constrained by the undeveloped status of contemporary methods, thus making it difficult to meet Durkheim's strict positivist dictum: "The first and most fundamental rule is: Consider social facts as things" (Durkheim 1966, p. 14). Thus, according to Mauss, it fell upon the future generations of Durkheimians to meet the methodological challenge of measuring morphological space as a thing: "we already know how far the historian and sociologist of the coming generations will be better armed than we were" (Mauss 2005, p. 70). The space syntax approach belongs to this emerging methodological future of Durkheimian scholarship. Equipped with space syntax tools scholars may, for the first time, quantify the "non-discursive regularity" (Hillier 1996) of space as a "social fact", and thus systematically examine this exterior and restraining "thing" as an agential force that shape dynamic densities and social life. 


\section{A Problematic Alliance with the Durkheimian Macro-Wing}

While Hillier and Hanson (1984) reappraise the explanatory scope of Durkheimian social morphology (both in terms of their argument for real spatial agency and the development of methods to capture spatial morphologies), they hold on to the physiological solidarity-outcome outlined in Division. As such, the principal axiom of space syntax is that the difference between the trans-spatial relationships of the inside, and the spatial relationships of the outside, corresponds with distinct morphological organisations and spatial means by which social solidarities are reproduced. Thus, consistent with Durkheim's distinction between mechanical and organic solidarity, they assume a duality by which society generates space, and

this duality is a function of different forms of social solidarity. ... One requires a strong control on boundaries and strong internal organisation in order to maintain an essentially transspatial form of solidarity. The other requires weak boundaries, and the generation rather than the control of events (Hillier and Hanson 1984, p. 20).

With this argument, we suggest that Hillier and Hanson ally themselves with the structural functionalist macro-wing of the Durkheimian tradition (see Collins 1994), famously advocated within sociology by, among others, Parsons (1977). This assertion extends and further specifies Netto's (2016) argument that Hillier and Hanson have roots in Durkheimian structuralism, as well as Seibert's (2006) suggestion that space syntax displays certain "functionalist undertones". In a structural functionalist perspective, society is considered an ordered totality or social organism, holding a number of "functional requisites" or "social needs", which the structural parts of society exist in order to reproduce (Turner and Maryanski 1979). Hillier and Hanson's sociology of the elementary cell appears largely consistent with such an understanding of functional requisites morphological space is perceived as being organised in order to reproduce the trans-spatial and spatial needs for mechanical and organic solidarity, respectively:

Could it be that different types of society required different kinds of control on encounters in order to be that type of society; because if this were so, we could reasonably expect it to be the deepest level at which society generated spatial form (Hillier and Hanson 1984, p. 18). 
Justified as an extesion of the Durkheimian assertion that the division of labour fulfils a functional need for social solidarity, Hillier and Hanson (see also p. 254) suggest, in other words, that the spatial organisation of societal entities serves as a morphological means to fulfil a higherorder functional requisite. What challenges this argument, however, it is the fact that Durkheim himself would be more than sceptical towards the teleological reasoning applied. Insisting on the contingency (as opposed to any teleology) of historical evolution, Durkheim (1966, p. 95) argues that "social phenomena do not generally exist for the useful results they produce". The progressive division of labour did not develop in order to fulfil a functional need for conciliatory solidarity; one must draw a sharp line between teleological (and thus illegitimate) "functional explanations" and scientifically valid "causal explanations". As such, we "cannot use 'aim' or 'purpose', and speak of the goal of the division of labour, because that would suppose that the division of labour exists for the sake of results that we shall determine" (Durkheim 1984, p. 11). Yet, this is what Hillier and Hanson assume: The spatial structure of society is organised in a manner that fulfils the purpose of reproducing the societal system. This view manifests how Hillier and Hanson are more closely allied with the Durkheiman macro-wing than with Durkheim himself and his anti-teleological stance.

Durkheim rejected teleological explanation because he aimed to legitimise sociology as a positive empirical science, in contrast to a philosophical speculation and metaphysics. Thus, it is no coincidence that the Division quotes Aristotle's Politics on its title page: “A city is not made up of people who are same; it is different from an alliance" (Durkheim 1964, p. viii). On the one hand, Durkheim thus acknowledged Aristotle as the originator of the distinction between same-ness-based mechanical solidarity and organic solidarity based upon urban difference and heterogeneity. On the other hand, he indicated that his treatment of the subject were to be based in positive social facts, in contrast to Aristotle's reliance on teleological reasoning.

Interestingly, Hillier and Hanson (1984) also consider teleological explanations as an Aristotelian problem (see Weissenborn 2015). This is evident in their critique of Aristotle's argument concerning how nature achieves successful form-function relationships by design. Drawing an analogy with architecture, Aristotle assumes that built "forms" should not be explained mechanically as having material causes but teleologically with reference to their "functional" purposefulness. According to Hillier and Hanson, however, this explanation is illegitimate because Aristotle established the causal sequence connecting functional purposes and built with a metaphysical notion of "final causes": "On this architectural foundation the whole fallacious 
structure of Aristotelian 'science' was erected” (Hillier 1985, p. 63). Having rejected the existence of an Aristotelian "meta-structure" capable of coordinating the theological evolution of reality, Hillier and Hanson (1984) set out to find an equally efficient, but strictly socio-physical, explanation of how morphological space is coordinated into a built form that may reproduce the functional requisites for social solidarity. The solution is to locate society's "description centre", by which they mean a kind of social information or "DNA", in material reality itself, rather than in a metaphysical space beyond reality - yet still capable of "programming" the behaviour of individuals in a manner that promotes what is functionally required:

The structured information on which the system runs is not carried in the description mechanism but in reality itself in the spatio-temporal world. The programme does not generate reality. Reality generates a programme, one whose description is retrievable, leading to self-reproduction of the system under reasonable stable conditions (Hillier and Hanson 1984, p. 44).

As such, societal teleologies are to be accounted for in socio-physical terms as a "retrievability" of description, which emerges as reality "embodies" its own output. While Aristotelian teleology assumes that reality is dragged towards a teleological description centre, Hillier and Hanson (1984) replace this metaphysical logic with a "reality sandwich" schema: Reality builds into its time-spatial organisation the coordinating information needed to reproduce the solidarity requisite: "reality $1 \rightarrow$ description $\rightarrow$ reality 2 ". However, rather than being an antiteleological argument as such, Hillier and Hanson's reality sandwich schema seems to legitimise the structural functionalist teleology by means of spatial morphology. The meta-physical understanding of teleology is substituted with a morphological-physical counterpart, suggesting that spatial form carries the information needed to regulate social exchanges, so that they can be purposeful for the reproduction of the social needs of society. In the view of this, it should not come as a surprise that Hillier and Hanson evaluate the morphological reproduction of the solidarity requisite in terms such as "normal", "healthy", and "pathological" - similar to Durkhiem's (2005a) problematic concept of anomie, at the peak of his macro-functionalist theorising.

As Turner and Maryanski (1979) point out, teleologies often appear alongside similarly illegitimate tautologies in functionalist theorizing, by which "variables are defined in terms of each other, thus making the causes and effects obscure and difficult to assess" (p. 124). In our view, 
Hillier and Hanson's reality sandwich schema also reassembles such a system of tautological reasoning. The circular argument advanced is that the morphological organisation of society meets the integrative need of the society, while the persistence of the same societal whole allows this morphological organisation to persist. Tautological explanations of why society functions, however, say little more than what is already implied in the initial description of society as having certain social needs. As such, the reality sandwich scheme hypostatises the structural functionalist assumption that society is an organic whole with social end-needs.

The broader sociological issue at stake is that society is not comparable to a reproducing organism, given that only humans have telos-like purposes and inherent, social needs (Giddens 1979). Further, in contrast to the functionalist-like view that socio-spatial systems tend to "conserve the present" (Hillier and Hanson 1984, p. 44), and that cities are "nearly ordered" rather than "nearly chaotic" (Hillier 1999b), it is thoroughly ahistorical not to appreciate contingency, complexity, and conflict, to be sociologically important dynamics (Griffiths 2011; O'Sullivan 2000). Addressing this blind spot in space syntax theory, Bafna (2003) argues that the evolution of building layouts are "not entirely explainable on the grounds of generic social function", but rather have to be accounted for as "unintended consequences". This argument "presents a considerable challenge to space-syntactical accounts for why buildings take the forms that they do, since the basic premise in such accounts is that sociological factors are the primary forces in determining the internal forms of buildings" (Bafna 2003, p. §1). In our view, Bafna's critique is correct, although he overlooks the circumstance that an over-emphasis of generic social functions at the expense of an appreciation of unintended consequences is not an issue of sociology as such (see Giddens 1976; Merton 1936), but is inherited from a specific sociological school: structural functionalism.

Next, we highlight another issue that arises from space syntax's affinity with the macrowing of Durkheimian sociology, namely the existence of an analytical gap between the microdetailed resolution of the space syntax method (intended to represent the human and design scale of built environments) and the macro-theoretical nature of the Durkheimian concepts applied by Hillier and Hanson. In comparison with other (e.g. geographical) quantitative techniques measuring spatial properties, space syntax works on a "finer level of resolution", allowing it to measure "the ways in which space 'works' at the level of patterns of movement” (Hillier 1996, p. 140). Ideally, such fine-grained spatial perspective should be coupled with micro-sociological theories of face-toface interaction dynamics, but the Durkheimian macro-wing contains few such concepts (Collins $1983 ; 1994)$. As such, the space syntax applies a sociological lens that is too macroscopic to take 
full advantage of the design-level analysis rendered possible by its micro-methodology (Marcus 2015). In particular, this is true with respect to Hillier and Hanson's key spatial-morphological notions of movement and co-presence, which are derived from Durkheim's macro-sociological considerations on population densities.

A further reason for this incongruity is that the foundational theoretical work in space syntax was developed a decade or more (in the 1970s and 1980s) before the maturity of its methodological model of network analysis (using computer software that emerged in the 1990s). This early work was focussed more on establishing fundamental spatial-morphological typologies than on patterns of movement and encounter as such. Taken together, while space syntax offers a novel methodology to explain and predict the where of movement and co-presence in relation to spatial network configurations, the lack of accompanying micro-sociological concepts has hindered it from providing an adequate account of why such morphological variations promote solidarity (or other social outcomes, for that matter).

\section{From Virtual Communities to Actualised Interaction Rituals}

We propose that the structural functionalist bias and the lack of micro-sociological theory to accompany the micro-methodological sensitivity of space syntax may be addressed by a closer affiliation of space syntax with the Durkheimian "micro-wing". This tradition is defined by its rejection of structural functionalism in favour of micro-detailed description on how and why social solidarities are produced in dense face-to-face interaction situations (Collins 1994; 2004). Importantly, proponents of the micro-wing downplay the importance of Division in favour of Durkheim's The Elementary Forms. As Collins - today's arguably most influential microDurkheimian scholar - put it:

the strength of the Durkheimian tradition has been its contribution to micro-sociology, rather than as a theory of the macro-level societal integration or social evolution. Especially in The Elementary Forms, Durkheim provides a model of how solidarity and shared symbols are produced by interaction in small groups (Collins 2004, pp. 14-15).

Thus, contrary to Hillier and Hanson who almost exclusively cites Division and emphasise that "[w] hatever it is, society is not a dance or a ritual" (1984, p. 202), a central proposition of the Durkheimian micro-wing (especially as outlined in Collins' interaction ritual theory) is that society 
is to be explained as chains of ritual interactions which are defined by their dance-like nature! Specifically, Collins (2004) highlights that successful micro-interactions involve that participants become "rhythmically entrained" (see also Turner 2010). This is to be understood as a neurologically hardwired capacity for humans to synchronise with others' motions and emotions when co-present (Heinskou and Liebst 2016). Further, such entrainment processes are considered a key "micro-morphological" condition for why interaction rituals produce social solidarity: "Rhythmic synchronization is correlated with solidarity" (Collins 2004, p. 76; for meta-analytical evidence supporting this assertion, see Mogan, Fischer, \& Bulbulia 2017).

Here, a theoretical reservation might be that a social "dance" or "ritual" are codified social activities requiring a choreographer. Yet, noting the contributions of Jacobs' (1961) "sidewalk ballet”, Seamon's (2007) “place-ballets”, and Pred's (1977) characterisation of time-geography as the "choreography of existence", it should be recognised that dance-like ritual forms may emerge without the need for a choreographer. Indeed, such everyday noise of movement and encounter may be the proper subject of "spatial cultures" (Griffiths 2016).

Another objection might be that our argument is theoretically inconsistent, given that Durkheim's (1995) late sociology of religion - which forms the backbone of Collins' subsequent micro-sociology - is often considered the least morphologically-based domain of Durkheimian scholarship. For example, according to Alexander (1995, p. 136), "Durkheim reached his theoretical maturity after a prolonged, if confused, flirtation of with materialist forms of structural theory, and eventually a fierce struggle against them." Significantly for the argument advanced here, however, Collins (1995, p. 133) suggests to the contrary that "Durkheim never abandoned his concern for social morphology; he refined it to the level of the micro-morphology of the group interaction, and brings out explicitly the emotional nature of this interaction". For example, Durkheim's (1995) proposition that religious emotions and symbols arise as individuals "assemble", "gather", or "concentrate" should simply be understood as a micro-interactional adaptions of his fundamentally morphological insight that social densities shape social life. Durkheim's vocabulary might change, but he retained a density-based explanation (see Liebst 2015). Similarly, it should be stressed, that Durkheim's ambivalence regarding the agency of the social morphology should not be confused as an ambivalence towards social morphological explanations as such.

The persistent emphasis on morphological factors is further stressed by the fact that Mauss (1979 [1906]), Durkheim's nephew and close collaborator, published a study on the seasonal morphology of the Inuit culture a decade after Durkheim allegedly (according to Alexander 2005) 
had abandoned his social morphology. The clear-cut morphological argument of this study is that the dense and dispersed spatial living conditions during winter and summer are associated with inverse levels of ritual intensity: "Winter is a season when Eskimo society is highly concentrated and in a state of continual excitement and hyperactivity" (Mauss 1979, p. 76). These are the types of micro-morphological insights that are further elaborated in Collins' (2004) micro-sociology, which, therefore, offers the most comprehensive work to advance the Durkheimian outlook of space syntax.

It should be noted that space syntax theory, in fact, does contain some elements of microsociological theorising, in particular, the concept of "virtual communities" (Hillier et al. 1987). This describes the sense of awareness - prior to the occurrence of any actualised face-to-face interaction - that exists between co-present strangers, densified in integrated street segments by the agency of networked spatial morphologies (Palaiologou, Griffiths and Vaughan, 2016). As such, this idea resembles Goffman's (1964, p. 135) understanding of social situations, described "as an environment of mutual monitoring possibilities, anywhere within which an individual will find himself accessible to the naked senses of all others who are 'present', and similarly find them accessible to him". For Goffman, this minimal awareness among those co-present is the precondition for any further social encounters and commitments (such as the emergence of weak solidarity ties among urban strangers, see Horgan 2012). However, contrary to Goffman, Collins, and the micro-sociological tradition in general, Hillier and Hanson say almost nothing about the proceeding (or prior) interaction dynamic, which may arise from minimal situational awareness. An analysis of these dynamics would require a broader micro-sociological description of how microinteractions unfold, including an appreciation of their dance and ritual-like nature.

Accommodating this need for expanding the micro-sociological scope of space syntax theory, we sketch out Collins' micro-Durkheimian theory of the interaction ritual, and subsequently consider how this theory can productively engage with the space syntax approach. What renders this dialogue possible is the circumstance that both space syntax and Collins, despite their origin within different paradigms, share a Durkhemian social-morphological ontology: social life has a tangible basis in spatially co-present individuals. According to Collins' view, however, such gathering of individuals in the same space concern only one of the four ritual ingredients underpinning social life (see Figure 2). Further, participants in social micro-rituals share both a focus of attention and a common emotional mood, and the encounter is spatially demarcated to ensure a sense of who is partaking. These ritual ingredients reinforce one another through feedback 
effects; a reciprocal effect between the joint focus of attention and the shared mood is especially important, proceeding as micro-sequences of rhythmic entrainment among the bodily co-present participants.

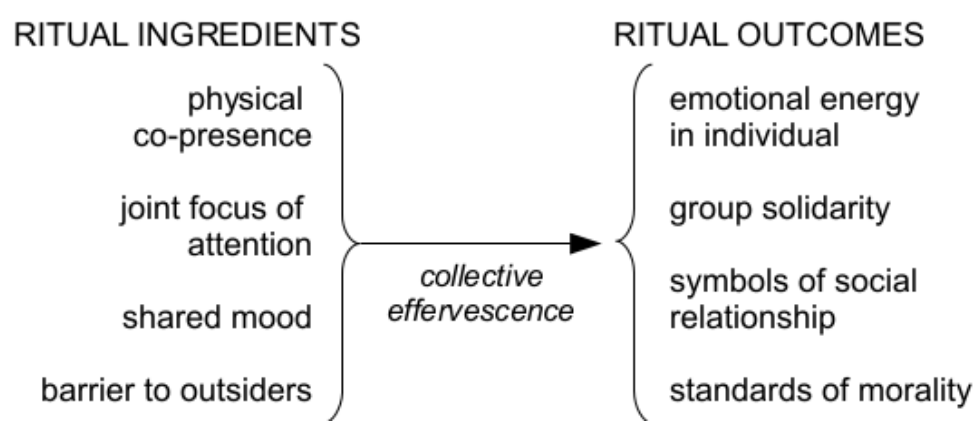

Figure 2. Model of interaction rituals. Simplified from Collins (2004).

Depending on the composition of the ritual ingredients, the interaction ritual generates varying degrees of "collective effervescence", experienced as a "sort of electricity" (Durkheim $1995)$ that intensify the ritual situation. This collective emotional arousal produces a number of ritual outcomes. An emotional energy (EE), which creates motivation for further involvement in similar ritual activity. The participants experience group solidarity and a feeling of membership. Finally, there is an emergence of symbols that represent the group, and the intense emotions experienced crystallise into a group-specific moral frame.

In advocating the relevance of Collins' work to the translation of space syntax theory for the sociology of space, we return to Figure 1 that summarises the finding that the network configuration inverts the conventionally accepted relation between movement and attraction, by asserting that the configuration itself is the primary source of movement and land use distributions. Hillier (1996) elaborates this insight in his theory of "cities as movement economies", which arguably is the most influential aspect of the space syntax theory (Liebst 2015). Similar to Jacobs (1961), the ambition is to identify the spatial architectural underpinning of well-functioning urban places, and Hillier specifically suggests that street asymmetries in grid configuration, initially, generates differential patterns of urban movement. Or put in other words, movement flows tends to concentrate in spatially integrated street segments. Subsequently, these movement concentrations "influence land use choices, and these in turn generate multiplier effects on movement with further feed-back on land use choices and the local grid as it adapts itself to more intensive development" (Hillier 1999a, p. 06.2). The paradigmatic example of this configurationally facilitated movement-attraction 
dynamic is the clustering of retail activities in spatially integrated locations, where shops can take economic advantage of the presence of high rates of footfall and thus potential customers. Evidence supports this movement economic dynamic (Scoppa and Peponis 2015), which also has been extended to explain the emergence of phenomenologically attractive urban space - in which the liveliness of movement dense streets are felt alluring (Liebst 2015).

While the analytical strength of this movement economy theory is how it succeeds in establishing a surprisingly simple, yet empirically plausible, association of street grid configuration, movement, and emplaced attraction, the theory remains vague with respect to the notion of human motivation, which is assumed with its references to "attraction" and "choice". It is far from selfexplanatory why individuals find something attractive and choose worthy (Collins 1993). Are we, for example, dealing with the rational choice behaviour of homo oeconomicus, or perhaps a more emotionally driven and non-economic motivation of being in lively urban public places; both readings of the theory are possible (see Liebst 2015). Or, does Penn's (2003, p. 30) argument that space syntax theory does simply not assume "anything about individuals or their cognitive capacity" summarise what the movement economic theory strives for? Given that the theory already incorporates individual cognitive assumptions - as any social theory arguably needs to do (Smith 2015 ) - its scientific validity hinges on the clarification of these motivational questions.

This leads us back to Collins (2004), whose interaction ritual theory includes a model of micro-situation cognition and specifically proposes that the chief motivational force of human behaviour is a search for emotional energy $(\mathrm{EE})$, produced by successful interaction rituals. Conceptualised in this way, humans may be considered EE-seekers, operating on "markets" for interaction rituals: "one seeks EE according to what is immediately attractive, and what is emblematic of past EE payoffs" (Collins 2004, p. 174). This offers a plausible way to explicate the missing motivational dimension in Hillier's movement economic theory and establish its broad reference to sociological questions, especially with respect to its predictions regarding the "pleasure", "urban buzz", and "experiences" of cities at their best (Hillier 1996). As such, the movement economic axiom that "configuration generates attraction" (Hillier 2002) may be specified in micro-sociological terms as a process by which the configurational effects on movement and dense co-presence patterns promote EE-attractive opportunities for interaction ritual exchanges. This micro-Durkheimian reassessment of movement economies as interaction ritual markets may be summarised into a synthesis of Hillier's Figure 1 and Collins' Figure 2: 

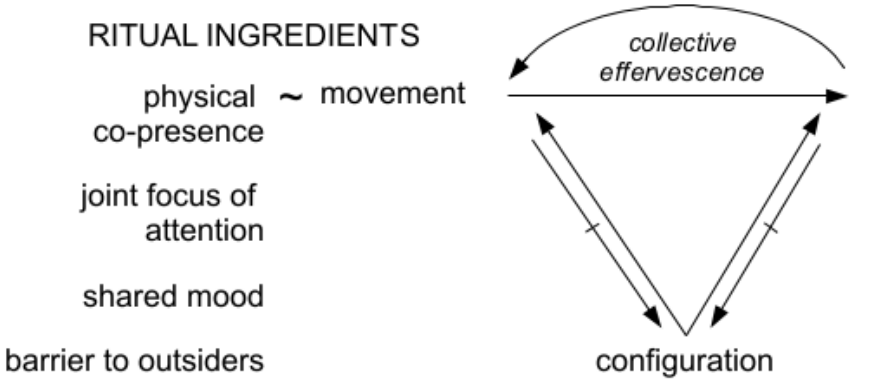

RITUAL OUTCOMES

attraction emotional energy

in individual

group solidarity

symbols of social

relationship

standards of morality

Figure 3. Movement economies as interaction ritual markets. Author's creation.

Two conceptual linkages make this Collins-Hillier framework possible. First, the outcome variable of "attraction" is explicated in micro-sociological terms as an "individual emotional energy". Secondly, the ritual variable of "physical co-presence" corresponds to the space syntax understanding of "movement", given that co-presence is simply a gathering or movement of human bodies into the same space.

Further, it should be added that this model synthesis does not only lends micro-sociological clarity to space syntax theory, but also nudges Collins' micro-sociology in a more explicitly spacemorphological direction and thus beyond the anthropocentric view that he shares with Durkheim: "time, space, and numbers do not do anything; all real causal forces must come from human beings acting in some situation" (Collins 1983:187). That is to say, while Collins assumes that it is due to the EE-seeking agency of humans that rituals processes begin, the space syntax theory reminds us that space may also hold the agential capacity to facilitate ritual interaction by channeling bodies into the same place (Liebst 2016). Whether it is human or non-human agency that is responsible for the creation of dense urban co-presence, the outcome is the same experience of being "where the action is", arising in cities as "the minimal excitement of being within a mass of human bodies" (Collins 2004, p. 82). In this view, space plays a larger role for the orchestration of interactional encounters than traditionally assumed within sociology (e.g. Gans 2002), yet without turning into an architectural determinism. "Space does not direct events, but it does shape the probability", as Hillier (1996, p. 155) summarises the case pragmatically.

\section{Closing Remarks}

The discussion in this article has been conducted at a level of theoretical abstraction. We would like to end on a more applied note by considering how space syntax can usefully enhance 
empirical studies in micro-sociology. This reflection is prompted by the straightforward observation that space syntax and micro-sociology operate at the same fine-grained level of "human-scale" analysis. Moreover, space syntax scholars have for decades practiced what micro-sociologists, including Collins (1983) and Goffman (1971), are increasingly advocating methodologically: the application of systematic social observations of real-life human behaviours, as they unfold in their natural spatial setting (Raudenbush and Sampson 1999; Reiss 1991).

It is an integral part of the space syntax methodology to systematically record both movement flows and patterns of co-presence through real-world observational studies (Griffiths 2014). Such social morphological properties are similarly recorded in micro-sociological observational studies, which however also would involve recording a broader palette of behavioural patterns. For example, besides physical displays of movement and co-presence, this include: how people are acting when alone, minimally aware, or in groups; cues of emotions and social relationship ties; the degree of spatial proximity between participants; or the degree of dance-like synchrony between those co-present (see e.g. Afifi and Johnson 2005; Collins 1983; Dael et al. 2012; Hall 1966; McPhail and Wohlstein 1986). By developing a wider repertoire of behavioural observation, space syntax would achieve a far greater micro-sociological sensitivity. This would not only promote richer empirical analyses more sensitive to the micro-scale affordances of spatial configuration, but would also begin the process of dismantling those aspects of macro-wing Durkheimianism that, as we have shown, risks compromising the potential value of the space syntax perspective for sociologists.

One threshold for a wider interdisciplinary adoption of space syntax methods is that microsociological research rarely applies, but often challenges the relevance of, quantitative inquiries (Blumer 1956; but see Ulmer and Wilson 2003). As such, there is a dearth of micro-sociological research and methods allowing a statistical evaluation of the key assumptions in the above CollinsHillier model synthesis - in particular, the claim that the real agency of space may concentrate social densities and thus, in turn, intensify emplaced micro-rituals. One recent exception is Liebst (2019), who combines Collins' interactions ritual theory and space syntax methods to quantitatively examine the influence of spatio-morphological crowding on collective effervescence. Specifically, this study applied geo-referenced survey data and space syntax measures of crowding levels, which were then estimated with multilevel modelling; a technique appropriate for assessing spatial contextual factors (Logan 2012). Results showed that morphological crowding was a more influential predictor of collective effervescence than interactional and compositional features. Thus, 
besides supporting the link between morphological space, social densities, and emotional intensities, this study demonstrates how space syntax and statistical methods may be integrated in micro-sociological analyses in a manner that answers Blumer's (1956) criticism that quantification decontextualizes social life from its here-and-now situations. Taken together, this suggests that Raudenbush and Sampson's (1999) call for “ecometric" approaches to assess ecological setting could and should be extended to Durkheimian micro-sociology through an application of space syntax techniques.

\section{References}

Afifi, W.A. and M.L. Johnson. 2005. The nature and function of tie-signs. In The sourcebook of nonverbal measures: Going beyond words, ed. Manusov, VL, 189-98. New Jersey: Psychology Press.

Alexander, J.C. 2005. The inner development of durkheim's sociological theory: From early writings to maturity. In The cambridge companion to durkheim, eds Alexander, JC and Smith, P, 136-59. Cambridge: Cambridge University Press.

Bafna, S. 2003. The role of corporeal form in architectural thinking. In Proceedings of the Fourth Space Syntax Symposium. University College London, United Kingdom.

Blumer, H. (1956). Sociological analysis and the "variable". American Sociological Review, 21(6), 683-690.

Collins, R. 1983. Micromethods as a basis for macrosociology. Journal of Contemporary Ethnography 12, no 2: 184-202.

Collins, R. 1993. Emotional energy as the common denominator of rational action. Rationality and Society 5, no 2: 203-30.

Collins, R. 1994. Four sociological traditions. Oxford: Oxford University Press.

Collins, R. 2004. Interaction ritual chains. Princeton: Princeton University Press.

Collins, R. 2005. The Durkheimian movement in France and in world sociology. In The cambridge companion to Durkheim, eds Alexander, JC and Smith, P, 101-35. Cambridge: Cambridge University Press.

Dael, N., M. Mortillaro and K.R. Scherer. 2012. Emotion expression in body action and posture. Emotion 12, no 5: 1085-101.

Douglas, M. 1970. Natural Symbols: explorations in cosmology. London: The Cresset Press. 
Durkheim, É. 1960. Sociology and its scientific field. In Emile Durkheim, 1858-1917: A collection of essays, ed. Wolff, KH. Columbus: The Ohio State University Press.

Durkheim, É. 1964. The division of labor in society. London: Collier-Macmillan.

Durkheim, É. 1966. The rules of sociological method. New York: Free Press.

Durkheim, É. 1978. Sociology and the social sciences. In On institutional analysis, ed. Traugott, M. Chicago \& London: The University of Chicago Press.

Durkheim, É. 1984. The division of labor in society. New York: Free Press.

Durkheim, É. 1995. The elementary forms of the religious life. New York: The Free Press.

Durkheim, É. 2005a. On suicide. London: Penguin Press.

Durkheim, É. 2005b. Review of antonio labriola, essays on the materialist conception of history. In Readings from emile durkheim, ed. Thompson, K. London \& New York: Routledge.

Durkheim, É. and M. Mauss. 1963. Primitive classification. Chicago: The University of Chicago Press.

Foster, N. 1997. Opening Address. Proceedings: Space Syntax First International Symposium III, no. i, London: UCL.

Gans, H.J. 2002. The sociology of space: A use-centered view. City \& Community 1, no 4: 329-39.

Gans, H.J. 1968. People and plans: Essays on urban problems and solutions. London: Cox \& Wyman.

Giddens, A. 1976. Functionalism: Après la lutte. Social Research 43, no 2: 325-66.

Giddens, A. 1979. Central problems in social theory. Berkeley: University of California Press.

Goffman, E. 1956. The presentation of self in everyday life. Edinburgh: University of Edinburgh Social Science Research Centre.

Goffman, E. 1964. The neglected situation. American Anthropologist 66, no 6: 133-36.

Goffman, E. 1971. Relations in public. Microstudies of the public order. New York: Basic Books.

Griffiths, S. 2011. Temporality in hillier and hanson's theory of spatial description: Some implications of historical research for space syntax. The Journal of Space Syntax 2, no 1: 7396.

Griffiths, S. 2014. Space syntax as interdisciplinary urban design pedagogy. In Explorations in urban design: An urban design research primer, ed. Carmona, M, 158-67. Farnham: Ashgate.

Griffiths, S. 2016. Spatial culture, processional culture and the materialities of social memory in nineteenth-century sheffield. Distinktion: Journal of Social Theory 17, no 3: 254-75. 
Halbwachs, M. 1960. Population and society. Introduction to social morphology. New York: Free Press.

Hall, E. T. 1966. The hidden dimension. Garden City, NY: Doubleday.

Hanson J. 1976. Time and space in two nineteenth century novels. Architectural Association Quarterly 8 no. 4: 32-38

Hanson, J. 1999. Decoding homes and houses. Cambridge Cambridge University Press.

Heinskou, M.B., \& L.S. Liebst. 2016. On the Elementary Neural Forms of Micro-Interactional Rituals: Integrating Autonomic Nervous System Functioning Into Interaction Ritual Theory. Sociological Forum 31, no. 2: 354-376.

Hillier, B. and A. Leaman. 1973a. Structure, System, Transformation: Sciences of Organisation and Sciences of the Artificial. Transactions of the Bartlett Society 9: 36-77

Hillier, B and A. Leaman. 1973b. The man-environment paradigm and its paradoxes. Architectural Design 78 no. 8: 507-511

Hillier, B and A. Leaman. 1974. How is design possible? Journal of Architectural and Planning Research 3 no. 1: 4-11.

Hillier, B., A. Leaman, P. Stansall and M. Bedford. 1978. Space Syntax, in D. Green, C. Haselgrove and M. Spriggs .eds. Social Organisation and Settlement: contributions from Anthropology, Archaeology and Geography. BAR International Series (Supplementary) 47 no. ii: $343-384$.

Hillier, B. 1985. The nature of the artificial: The contingent and the necessary in spatial form in architecture. Geoforum 16, no 2: 163-78.

Hillier, B. 1989. The architecture of the urban object. Ekistics 56 no 334/33: 5-21.

Hillier, B. 1996. Space is the machine. Cambridge: Cambridge University press.

Hillier, B. 1999a. Centrality as a process: Accounting for attraction inequalities in deformed grids. In proceedings of the Second Space Syntax Symposium. Faculdade de Arquitetura e Urbanismo Universidade de Brasília, Brazil.

Hillier, B. 1999b. The hidden geometry of deformed grids: Or, why space syntax works, when it looks as though it shouldn't. Environment and Planning B: Planning and Design 26, no 2: 169-91.

Hillier, B. 2002. A theory of the city as object: Or, how spatial laws mediate the social construction of urban space. Urban Design International 7, no 3-4: 153-79. 
Hillier, B. 2005. Between social physics and phenomenology. In proceedings of the Fifth Space Syntax Symposium. Faculty of Architecture, Delft University of Technology, The Netherlands.

Hillier, B. 2008. Space and spatiality: What the built environment needs from social theory. Building Research \& Information 36, no 3: 216-30.

Hillier, B. 2010. What do We Need to Add to a Social Network to Get a Society?. The Journal of Space Syntax 1, no 1: 41-58.

Hillier, B., R. Burdett, J. Peponis and A. Penn. 1987. Creating life: Or, does architecture determine anything? Architecture et Comportement/Architecture and Behaviour 3, no 3: 233-50.

Hillier, B. and J. Hanson. 1984. The social logic of space. Cambridge: Cambridge University Press.

Hillier, B., A. Leaman, P. Stansall and M. Bedford. 1976. Space syntax. Environment and Planning B: Planning and design 3, no 2: 147-85.

Hillier, B. and V. Netto. 2002. Society seen through the prism of space: Outline of a theory of society and space. Urban Design International 7, no 3-4: 181-203.

Hillier, B., A. Penn, J. Hanson, T. Grajewski and J. Xu. 1993. Natural movement: Or, configuration and attraction in urban pedestrian movement. Environment and Planning B: Planning and Design 20, no 1: 29-66.

Hillier, B. and N. Raford. 2010. Description and discovery in socio-spatial analysis: The case of space syntax. In The sage handbook of measurement, eds Walford, G, Tucker, E and Viswanathan, M, 265-82. London: SAGE Publications.

Horgan, M. 2012. Strangers and strangership. Journal of Intercultural Studies 33, no. 6: 607-622.

Jacobs, J. 1961. The death and life of great american cities. New York: Random House.

Karimi, K. 2012. A configurational approach to analytical urban design: 'Space syntax' methodology. Urban Design International, 17, no: 297-318.

Latour, B. 1996. On interobjectivity. Mind, Culture, and Activity 3, no 4: 228-45.

Latour, B. and A. Yaneva. 2008. Give me a gun and I will make all buildings move: An ant's view of architecture. In Explorations in architecture: Teaching, Design, Research, ed. Geiser, R, 80-89. Basel: Birkhäuser.

Latour, B. 2005. Reassembling the social: An introduction to actor-network-theory. Oxford: Oxford University Press.

Levi-Strauss, C. (1974). Tristes tropiques. New York: Atheneum. 
Liebst, L.S. 2015. Phenomenology of the movement economy: A multilevel analysis. The Journal of Space Syntax 6, no 1: 49-60.

Liebst, L.S. 2016. Reassembling durkheimian sociology of space. In Spatial cultures: Towards a new social morphology of cities past and present, eds Griffiths, S and Von Lünen, A, 21424. London and New York: Routledge.

Liebst, L.S. 2019. Exploring the Sources of Collective Effervescence: A Multilevel Study. Sociological Science, 6: 27-42.

Lindemann, G. 2011. On latour's social theory and theory of society, and his contribution to saving the world. Human Studies 34, no 1: 93-110.

Logan, J.R. 2012. Making a place for space: Spatial thinking in social science. Annual Review of Sociology 38: 507-524.

Löw, M. 2008. The intrinsic logic of cities. In proceedings of the Seventh International Space Syntax Symposium. KTH Royal Institute of Technology, Sweden.

Löw, M. 2016. The sociology of space: Materiality, social structures, and action. London: Springer.

Marcus, L. 2015. Interaction rituals and co-presence-linking humans to humans in space syntax theory. In proceedings of the Tenth Space Syntax Symposium. Space Syntax Laboratory, University College London, United Kingdom.

Massey, D. (2005) For Space. London: Sage.

Mauss, M. 1979. Seasonal variations of the eskimo: A study in social morphology. London: Routledge \& Kegan Poul.

Mauss, M. 2005. Ed. Oxford, NY. The nature of sociology Durkheim press/berghahn books.

McPhail, C. and R.T. Wohlstein. 1986. Collective locomotion as collective behavior. American Sociological Review 51, no 4: 447-63.

Merton, R.K. 1936. The unanticipated consequences of purposive social action. American Sociological Review 1, no 6: 894-904.

Mogan, R., R. Fischer and J.A. Bulbulia. 2017. To be in synchrony or not? A meta-analysis of synchrony's effects on behavior, perception, cognition and affect. Journal of Experimental Social Psychology 72: 13-20.

Netto, V.M. 2016. 'What is space syntax not?'reflections on space syntax as sociospatial theory. Urban Design International 21, no 1: 25-40. 
O'sullivan, D.B. 2000. Graph-based cellular automaton models of urban spatial processes. University College London. PhD diss., University of London.

Palaiologou, G., Griffiths, S., Vaughan, L. 2016. Reclaiming the virtual community for spatial cultures: Functional generality and cultural specificity at the interface of building and street. Journal of Space Syntax 7, 1: 25-54.

Penn, A. 2003. Space syntax and spatial cognition: Or why the axial line? Environment and Behavior 35, no 1: 30-65.

Pred, A. 1977. The choreography of existence: Comments on hägerstrand's time-geography and its usefulness. Economic Geography 53, no 2: 207-21.

Raudenbush, S.W. and R.J. Sampson. 1999. Ecometrics: toward a science of assessing ecological settings, with application to the systematic social observation of neighborhoods. Sociological Methodology 29, no 1: 1-41.

Reiss, A. J., Jr. 1991. The trained incapacities of sociologists. In Sociology and its publics, eds Halliday, TC and Janowitz, M, 297-315. Chicago: University of Chicago Press.

Saunders, P. 2003. Social theory and the urban question. London: Routledge.

Schlanger, N. 2006. Introduction. In Techniques, technology and civilization, ed. Mauss, M. New York \& Oxford: Durkheim Press.

Seamon, D. 2007. A lived hermetic of people and place: Phenomenology and space syntax. In proceedings of the Sixth Space Syntax Symposium. Faculty of Architecture, Istanbul Technical University, Istanbul, Turkey.

Seibert, J. 2006. Introduction. In Space and spatial analysis on archaeology, eds Robertson, EC, Seibert, JD, Fernandez, DC and Zender, MU. Calgar: University of Calgary Press.

Sharmin, S. and M. Kamruzzaman. 2018. Meta-analysis of the relationships between space syntax measures and pedestrian movement. Transport Reviews 38, no. 4: 524-550.

Smith, C. 2015. To flourish or destruct: A personalist theory of human goods, motivations, failure, and evil. Chicago: University of Chicago Press.

Smith, P. 1999. The Elementary Forms of Place and Their Transformations: A Durkheimian Model. Qualitative Sociology 22, 13-36.

Soja, E. 2001. In different spaces: Interpreting the spatial organization of societies. In proceedings of the Third Space Syntax Symposium. Atlanta Georgia Institute of Technology, USA.

Tonboe, J. 1993. Rummets sociologi. København: Akademisk forlag. 
Turner, J. H. 2010. Theoretical Principles of Sociology Vol. 2. Microdynamics. New York: Springer.

Turner, J.H. and A. Maryanski. 1979. Functionalism. Menlo Park: Benjamin-Cummings Publishing Company.

Turner, V. 1977. The Ritual Process. Ithaca: Cornell University Press.

Ulmer, J.T. and M.S. Wilson. 2003. The potential contributions of quantitative research to symbolic interactionism. Symbolic Interaction 26, no. 4: 531-552.

Warf, B. and S. Arias. 2008. The spatial turn: Interdisciplinary perspectives. London: Routledge.

Weissenborn, F. 2015. After structure: Expression in built form. The Journal of Space Syntax 6, no 1: $34-48$. 